Article

\title{
Cytokinin-Facilitated Plant Regeneration of Three Brachystelma Species with Different Conservation Status
}

\author{
Nqobile P. Hlophe ${ }^{1}$, Adeyemi O. Aremu ${ }^{1,2, *}$, Karel Doležal ${ }^{3,4}{ }^{\oplus}$, Johannes Van Staden ${ }^{1, *}$ \\ and Jeffrey F. Finnie ${ }^{1, *}$ \\ 1 Research Centre for Plant Growth and Development, School of Life Sciences, University of KwaZulu-Natal \\ Pietermaritzburg, Private Bag X01, Scottsville 3209, South Africa; hlophe_n@yahoo.com \\ 2 Indigenous Knowledge Systems (IKS) Centre, Faculty of Natural and Agricultural Sciences, \\ North-West University, Private Bag X2046, Mmabatho 2790, South Africa \\ 3 Laboratory of Growth Regulators, Faculty of Science, Palacký University \& Institute of Experimental Botany \\ AS CR, Šlechtitelů 11, CZ-783 71 Olomouc, Czech Republic; karel.dolezal@upol.cz \\ 4 Department of Chemical Biology and Genetics, Centre of the Region Haná for Biotechnological and \\ Agricultural Research, Faculty of Science, Palacký University, Šlechtitelů 27, \\ CZ-783 71 Olomouc, Czech Republic \\ * Correspondence: Oladapo.Aremu@nwu.ac.za (A.O.A.); rcpgd@ukzn.ac.za (J.V.S.); Finnie@ukzn.ac.za (J.F.F.); \\ Tel.: +27-18-389-2573 (A.O.A.); +27-33-260-5130 (J.V.S.)
}

Received: 31 October 2020; Accepted: 19 November 2020; Published: 26 November 2020

check for updates

\begin{abstract}
In Africa and Asia, members of the genus Brachystelma are well-known for their diverse uses, especially their medicinal and nutritional values. However, the use of many Brachystelma species as a valuable resource is generally accompanied by the concern of over-exploitation attributed to their slow growth and general small size. The aim of the current study was to establish efficient micropropagation protocols for three Brachystelma species, namely Brachystelma ngomense (endangered), Brachystelma pulchellum (vulnerable) and Brachystelma pygmaeum (least concern), as a means of ensuring their conservation and survival. This was achieved using nodal segments ( 10 mm in length) as the source of explants in the presence of different concentrations of three cytokinins (CK) namely $N^{6}$-benzyladenine (BA), isopentenyladenine (iP) and meta-topolin riboside ( $\left.m \mathrm{TR}\right)$, over a period of 6 weeks. The highest $(25 \mu \mathrm{M})$ concentration of cytokinin treatments typically resulted in significantly higher shoot proliferation. However, each species differed in its response to specific CK: the optimal concentrations were $25 \mu \mathrm{M} m \mathrm{TR}, 25 \mu \mathrm{M}$ iP and $25 \mu \mathrm{M}$ BA for Brachystelma ngomense, Brachystelma pulchellum and Brachystelma pygmaeum, respectively. During the in vitro propagation, both Brachystelma ngomense and Brachystelma pygmaeum rooted poorly while regenerated Brachystelma pulchellum generally lacked roots regardless of the CK treatments. Following pulsing (dipping) treatment of in vitro-regenerated shoots with indole-3-butyric acid (IBA), acclimatization of all three Brachystelma species remained extremely limited due to poor rooting ex vitro. To the best of our knowledge, the current protocols provide the first successful report for these Brachystelma species. However, further research remains essential to enhance the efficiency of the devised protocol.
\end{abstract}

Keywords: Apocynaceae; auxins; conservation; cytokinins; micropropagation; rooting; meta-topolin

\section{Introduction}

The genus Brachystelma R. Br. ex Sims is a member of the tribe Ceropegieae belonging to the sub-family Asclepiadoideae of the family Apocynaceae [1]. Brachystelma is the second largest genus in the tribe Ceropegieae and occurs in Australia, Southeast Asia, India and sub-Saharan Africa. About 90\% 
of species occur exclusively in sub-Saharan Africa [2]. In South Africa, Brachystelma species occur across all the nine provinces [3]. There are 85 Brachystelma species on the South African Red List data and $73 \%$ are endemic to South Africa. The best species representation is found in the Eastern Cape, with 23 endemic species, and KwaZulu-Natal, with 16 endemic species [3]. Other endemic species occur in other provinces in South Africa [3]. Their distribution is evidence of their variability in habitat preference. Some are found on mountain slopes with up to $3000 \mathrm{~mm}$ of annual precipitation, while others are found among rocks in grasslands with up to $200 \mathrm{~mm}$ of annual precipitation [2,4-6]. One common factor is the requirement for well-drained soils [2]. Brachystelma species are generally geophytes, although a small number have fusiform roots instead of a tuber [2,4]. The plants are small (inconspicuous in nature) and herbaceous, generally forming a cluster of deciduous stems with well-developed leaves [4]. The flowers are small and short-lived, and the name "Brachystelma", meaning "short crown", is associated with the often extremely small corona [4,5].

The tubers of several Brachystelma species are eaten raw or prepared by some indigenous groups in Africa, Asia and Australia [2,7-9]. Some Brachystelma species have also been reported as medicinal herbs against different disease conditions $[2,9,10]$. Given that Brachystelma are being utilized as food and as medicinal herbs, there is a threat to most Brachystelma species in nature, mainly due to their slow growth and encroachment on their natural habitats $[3,11,12]$. The natural regeneration (via seed) process of Brachystelma is one that is uncertain and very sparingly documented. Propagation of these geophytes via conventional methods, i.e., cuttings and seedlings, is either absent or not well documented. In addition, conventional methods are generally known to be inefficient compared to micropropagation [13-15]. Efficient conservation measures are of importance for the future of the genus Brachystelma, especially when their value is yet to be fully explored. Thus, we evaluated the effects of three cytokinins (CKs) on the in vitro propagation of three Brachystelma species occurring in South Africa.

\section{Materials and Methods}

\subsection{Explant Decontamination and Generation of Experimental Material}

Whole-plant material of the three Brachystelma (Brachystelma ngomense R. Br., Brachystelma pulchellum R. Br. and Brachystelma pygmaeum R. Br.) species were collected from the wild and maintained in a shade house (Figure A1). Based on South African National Biodiversity Institute (SANBI) Red List [3], Brachystelma ngomense, Brachystelma pulchellum and Brachystelma pygmaeum are classified as endangered (EN), vulnerable (VU) and least concern (LC), respectively. These plants were harvested (March and April 2015) from the Botanical Garden of the University of KwaZulu-Natal (UKZN), Pietermaritzburg, South Africa. Voucher specimens (Brachystelma ngomense, A. Shuttleworth 335 (NU), Brachystelma pulchellum, N. Hlophe 20 (NU) and Brachystelma pygmaeum, A. Shuttleworth 322 (NU)) were deposited at the UKZN Bews Herbarium (NU). Young slender stem and tuber explants were excised from the stock plants and thoroughly washed with running tap water.

In the laboratory, the plants were further washed with liquid detergent, followed by thorough rinsing with tap water. In the process of the surface decontamination treatment, the longest tender stem and tuber materials were submerged in $1 \%(w / v)$ Benlate ${ }^{\circledR}$ (Du Pont de Nemours Int., Atholl, Johannesburg, South Africa) for $30 \mathrm{~min}$, followed by a solution of $70 \%$ ethanol $(v / v)$ for $60 \mathrm{~s}$. This process was accompanied with frequent agitation of the solution to ensure maximum contact of plant materials with the sterilant. The plant material was then rinsed three times with distilled water. Thereafter, varying concentrations of two sterilants, namely sodium hypochlorite $(\mathrm{NaOCl})(v / v)$ and mercuric chloride $\left(\mathrm{HgCl}_{2}\right)(w / v)$, were used as independent treatments for surface decontamination of the plant materials. The sterilant solutions were supplemented with a few drops of the surfactant Tween 20. The plant material was kept in this solution for varying periods of time, during which the solutions were frequently agitated to allow for optimum contact with the solution. The plant materials were once 
again thoroughly rinsed three times with sterile distilled water under sterile conditions in a laminar flow bench.

In order to obtain the explants, surface-decontaminated plant materials were further divided into lengths of $\sim 10 \mathrm{~mm}$ each and inoculated into culture tubes containing $10 \mathrm{~mL}$ of full-strength Murashige and Skoog (MS) basal medium [16], supplemented with $30 \mathrm{~g} / \mathrm{L}$ sucrose and $0.1 \mathrm{~g} / \mathrm{L}$ myo-inositol and solidified with $8 \mathrm{~g} / \mathrm{L}$ bacteriological agar (Oxoid Ltd., Basingstoke, Hampshire, England). The agar was added after the $\mathrm{pH}$ of the medium was adjusted to 5.8 using either $\mathrm{HCl}$ or $\mathrm{NaOH}$ (Sigma-Aldrich, Steinheim, Germany) solutions. The medium was dispensed into culture tubes $(100 \mathrm{~mm} \times 25 \mathrm{~mm}$, $40 \mathrm{~mL}$ ) followed by autoclaving for $20 \mathrm{~min}$ at $121^{\circ} \mathrm{C}$ and $103 \mathrm{kPa}$. Sealed cultures were incubated under controlled environmental conditions in a growth room set at $25 \pm 2{ }^{\circ} \mathrm{C}$, a $16 \mathrm{~h} \mathrm{light} / 8 \mathrm{~h}$ dark photoperiod and photosynthetic photon flux (PPF) $40-50 \mu \mathrm{mol} \mathrm{m}{ }^{-2} \mathrm{~s}^{-1}$ provided by fluorescent tubes (Osram, L58W/640, Munich, Germany). The number of explants for the initial culture of each plant was approximately 50, depending on availability of plant material. After 4 weeks in the culture, the number of sterile explants per treatment was recorded as a percentage. The in vitro-derived aseptic shoots (serving as stem nodal explants) obtained from the sterilization stage were continually sub-cultured until sufficient material was available to conduct subsequent experiments.

\subsection{In Vitro Shoot Proliferation}

Upon obtaining sufficient plant material, we investigated the effects of three CKs, namely $N^{6}$-benzyladenine (BA), isopentenyladenine (iP) and meta-topolin riboside ( $m \mathrm{TR}$ ), on shoot proliferation. We purchased the BA and iP from Sigma-Aldrich (Steinheim, Germany), while $m$ TR was prepared in-house as previously described by Doležal et al. [17]. The full-strength MS basal medium was supplemented with $30 \mathrm{~g} / \mathrm{L}$ sucrose, $0.1 \mathrm{~g} / \mathrm{L}$ myo-inositol and varying concentrations $(1,5,10$ and $25 \mu \mathrm{M})$ of BA, iP and $m$ TR. For this experiment, the control was the MS basal medium without CKs. Stem nodal explants were excised to a length of $\sim 10 \mathrm{~mm}$ and inoculated into the media in culture tubes. The cultures, 25 replicates per treatment, were incubated using similar environmental conditions as previously described for the bulking-up stage. Data on the number of shoots per explant, the length of the longest shoot, the number of nodal segments, fresh weight, the number of roots and root length were recorded after a 6-week incubation period. This experiment was done simultaneously for all three species and was repeated.

\subsection{Ex Vitro Rooting and Acclimatization}

The in vitro-regenerated shoots $(>20 \mathrm{~mm}$ ) were washed in water to remove traces of agar. Ex vitro rooting was first investigated with the use of a 3 min pulse (dipping) treatment using $492.1 \mu \mathrm{M}$ $(100 \mathrm{mg} / \mathrm{L})$ indole-3-butyric acid (IBA). A second pulse treatment investigation was performed using $492.1 \mu \mathrm{M}$ of IBA for 3, 12 and $21 \mathrm{~min}$. After treatment with IBA, the shoots were potted in plastic planting trays ( $45 \mathrm{~mm} \times 15 \mathrm{~mm}$ per well) containing a 1:1 $(v / v)$ vermiculite:sand mixture. The potted shoots were irrigated with quarter-strength $492.1 \mu \mathrm{M}(100 \mathrm{mg} / \mathrm{L})$ of IBA and incubated in a mist house in which high relative humidity $(90-100 \%)$ was maintained using a high-pressure fog system. The plantlets were kept in the mist house during midwinter under natural $12 \mathrm{~h}$ light/12 dark photoperiod conditions for 3 weeks. Thereafter, the plantlets were transferred to a greenhouse with natural temperature (midday PPF of approximately $1000 \mu \mathrm{mol} \mathrm{m} \mathrm{m}^{-2} \mathrm{~s}^{-1}$ ) and natural photoperiodic conditions. The plantlets were watered with tap water every second or third day. Survival rate (\%) was monitored once every week for a period of 5 weeks in the greenhouse. The period for which survival rate was monitored was completely dependent on how long the plantlets survived under natural conditions.

\subsection{Data Analysis}

A complete randomized experimental design was used for all experiments. Collected data were analyzed using one-way analysis of variance (ANOVA). In order to establish statistical significances, the mean values were further separated using Duncan's multiple range test (DMRT) on SPSS for 
Windows (IBM Corp., Armonk, NY, USA). Significant treatment effects were accepted at $p \leq 0.05$. Graphic representations were created using SigmaPlot 8.0. (Systat Software, Inc., San Jose, CA, USA, www.systatsoftware.com).

\section{Results}

\subsection{Decontamination Responses}

The use of the $1.75 \%$ sodium hypochlorite $(\mathrm{NaOCl})$ treatment for 30 min was found to be most effective, as it resulted in the highest $(>60 \%)$ decontamination frequency. This treatment was used for the sterilization of all plant material in subsequent experiments (Table 1). The treatment was found to be equally effective for the three Brachystelma species.

Table 1. Surface decontamination of Brachystelma pygmaeum plant material using mercuric chloride $\left(\mathrm{HgCl}_{2}\right)$ and sodium hypochlorite $(\mathrm{NaOCl})$ for different time durations.

\begin{tabular}{cccc}
\hline Treatment & Duration (min) & Explant & Decontamination Success (\%) \\
\hline $\mathrm{HgCl}_{2}(0.1 \%)$ & 5 & Nodal & 0 \\
$\mathrm{HgCl}_{2}(0.1 \%)$ & 10 & Nodal & 9 \\
$\mathrm{HgCl}_{2}(0.2 \%)$ & 30 & Tuber & 0 \\
$\mathrm{NaOCl}(1.75 \%)$ & 30 & Nodal & 67 \\
$\mathrm{NaOCl}(3 \%)$ & 10 & Nodal & 20 \\
\hline
\end{tabular}

At this culture initiation stage, stem nodal explants of all three species were observed to have new growth either in the form of shoots or callus; however, a notable number of these explants showed no response (i.e., no elongation or shoot production). Callus was more frequently observed in Brachystelma pygmaeum compared with Brachystelma pulchellum and Brachystelma ngomense. Callus cultures of Brachystelma pygmaeum were observed to develop adventitious shoots after a period of 6-8 weeks (Figure A2).

\subsection{Effect of Cytokinins on In Vitro Shoot Proliferation}

The applied CK treatments generally improved shoot production in all three species (Figure 1). The number of shoots produced per explant for Brachystelma ngomense were higher with increasing concentrations of BA, iP and $m$ TR compared with the control (Figure 1A). The highest shoot production (4.44) was observed at $25 \mu \mathrm{M} m \mathrm{TR}$ in Brachystelma ngomense. On the other hand, Brachystelma pulchellum (Figure 1B) responded in a slightly different manner. There was no particular trend to show the effect of increasing CK concentration with BA and $m$ TR. However, iP increased shoot production with increasing concentrations. The highest shoot production $(2.04 \pm 0.20)$ was observed at $25 \mu \mathrm{M} \mathrm{iP}$, which was significantly higher than the control. For Brachystelma pygmaeum (Figure 1C), all treatments displayed a significantly higher shoot production per explant compared with the control, with the exception of $1 \mu \mathrm{M}$ iP and $m \mathrm{TR}$. Treatment with BA resulted in a significant increase in shoot production with increasing concentrations, while iP and $m \mathrm{TR}$ had a fluctuating response. In all three treatments, the higher concentrations resulted in better shoot production. The highest shoot production (2.57) was observed with the $25 \mu \mathrm{M}$ BA treatment.

In the current study, the shoot lengths and number of nodal segments of the three Brachystelma species generally had no significant difference between CK-treated explants and the control (Figures 2 and 3); however, a few exceptions were observed. The shoot length in Brachystelma ngomense (Figure 2A) was significantly increased by $5 \mu \mathrm{M}$ iP. The number of nodal segments in Brachystelma pulchellum (Figure 3B) and Brachystelma pygmaeum (Figure 3C) were significantly increased by $5 \mu \mathrm{M} m \mathrm{TR}$ and 5 $\mu \mathrm{M} B A$, respectively. To a certain degree, the application of CKs partly enhanced fresh weight in all three species (Figure 4A). The effect of BA, iP and $m$ TR on the fresh weight of Brachystelma ngomense (Figure $4 \mathrm{~A}$ ) was observed to be significantly higher in comparison with the control, with some 
exceptions. The highest fresh weight $(0.18 \mathrm{~g})$ was observed at $25 \mu \mathrm{M} m \mathrm{mTR}$. For Brachystelma pulchellum (Figure 4B), treatment with BA had no significant effect on fresh weight, while specific concentrations of iP and $m$ TR treatments significantly increased fresh weight compared with the control. The highest fresh weight $(0.10 \mathrm{~g})$ was observed at $5 \mu \mathrm{M} m \mathrm{TR}$. In Brachystelma pygmaeum (Figure 4C), fresh weight was significantly increased by all CK treatments compared with the control, with the exception of $1 \mu \mathrm{M}$ $\mathrm{BA}$ and $1 \mu \mathrm{M} m \mathrm{TR}$. The highest fresh weight $(0.23 \mathrm{~g})$ was achieved at $5 \mu \mathrm{M}$ BA and $5 \mu \mathrm{M}$ iP.

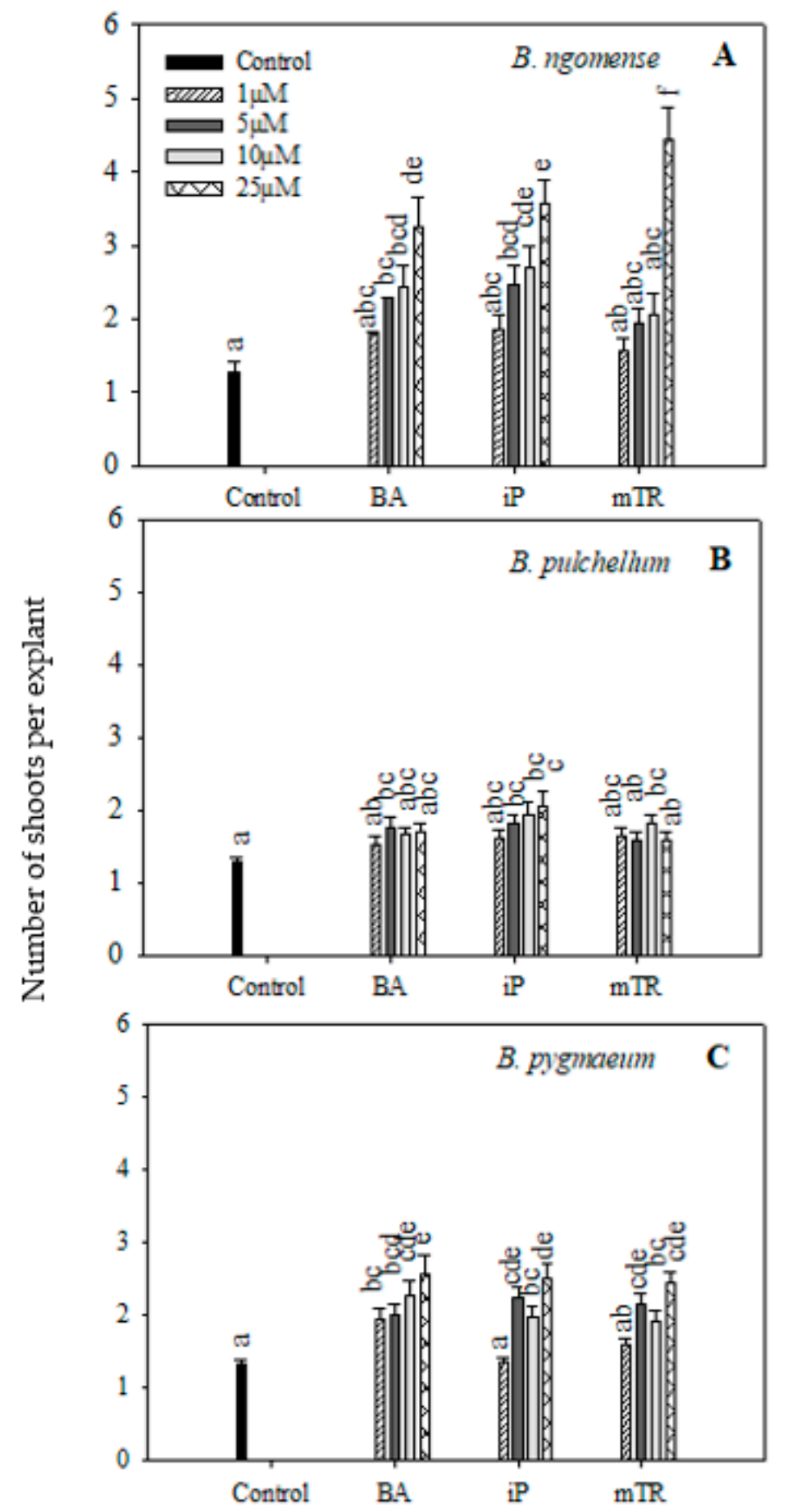

Figure 1. Effect of varying concentrations of cytokinins on shoot production in (A) Brachystelma ngomense, (B) Brachystelma pulchellum and (C) Brachystelma pygmaeum after six weeks in culture. In each graph, different letter(s) on the bars show significant differences according to Duncan's multiple range test (DMRT) $(p \leq 0.05) . N^{6}$-benzyladenine (BA), isopentenyladenine (iP) and meta-topolin riboside ( $m$ TR). 


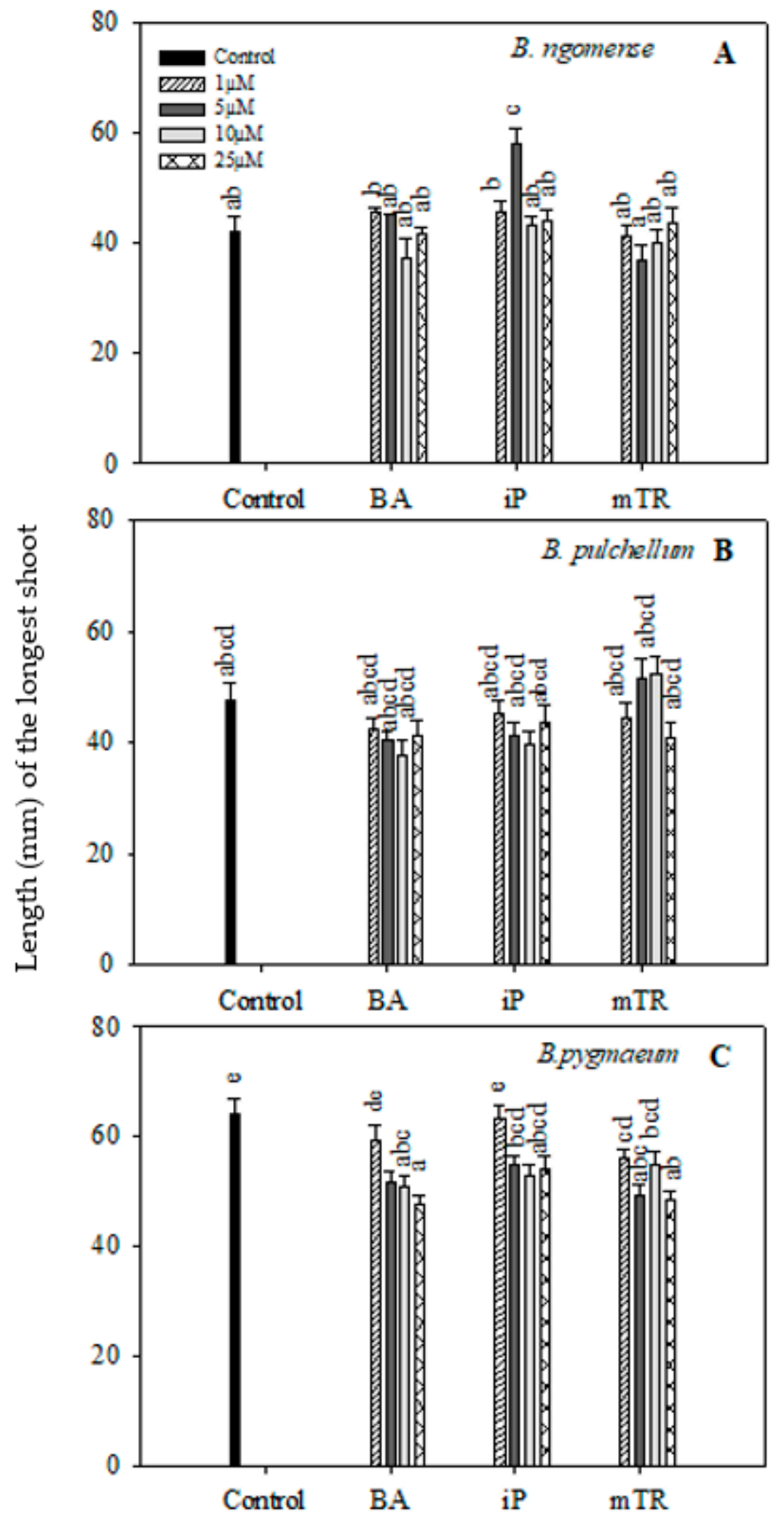

Figure 2. Effect of varying concentrations of cytokinins on the shoot length (mm) of (A) Brachystelma ngomense, (B) Brachystelma pulchellum and (C) Brachystelma pygmaeum after six weeks in culture. In each graph, different letter(s) on the bars show significant differences according to Duncan's multiple range test (DMRT) $(p \leq 0.05)$. $N^{6}$-benzyladenine (BA), isopentenyladenine (iP) and meta-topolin riboside ( $m \mathrm{TR})$. 


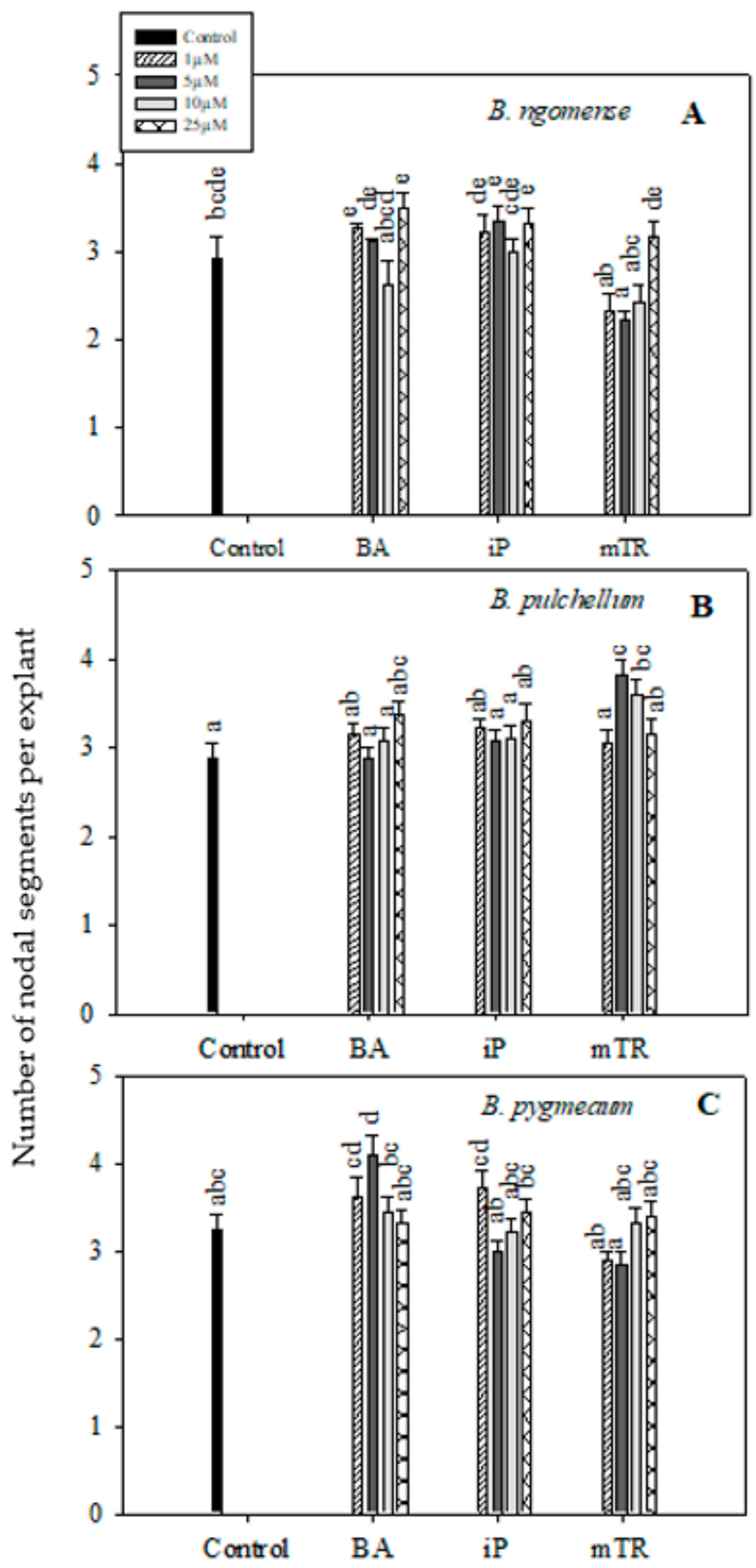

Figure 3. Effect of varying concentrations of cytokinins on the number of nodal segments in (A) Brachystelma ngomense, (B) Brachystelma pulchellum and (C) Brachystelma pygmaeum after six weeks in culture. In each graph, different letter(s) on the bars show significant differences according to Duncan's multiple range test (DMRT) $(p \leq 0.05)$. $N^{6}$-benzyladenine (BA), isopentenyladenine (iP) and meta-topolin riboside ( $m \mathrm{TR})$. 

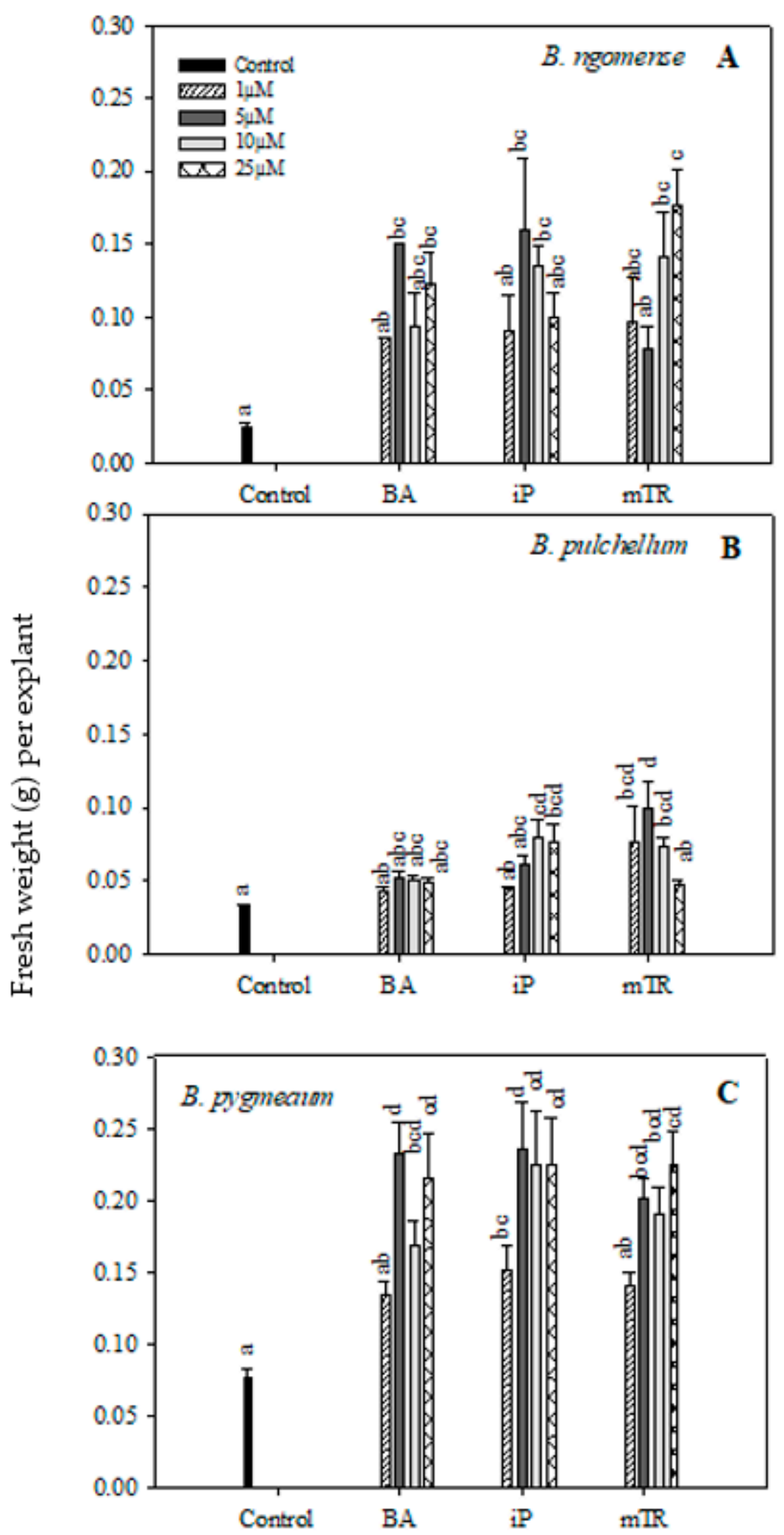

Figure 4. Effect of varying concentrations of cytokinins on fresh weight (g) in (A) Brachystelma ngomense, (B) Brachystelma pulchellum and (C) Brachystelma pygmaeum after six weeks in culture. In each graph, letter(s) on the bars show significant differences according to Duncan's multiple range test (DMRT) $(p \leq 0.05)$. $N^{6}$-benzyladenine (BA), isopentenyladenine (iP) and meta-topolin riboside ( $\left.m \mathrm{TR}\right)$. 
Although the primary aim of this particular experiment was to observe the effect of CKs on Brachystelma shoot growth parameters, rooting was also observed in in vitro-regenerated Brachystelma ngomense and Brachystelma pygmaeum shoots (Figures 5 and 6). The highest number of roots, as well as the longest root length, was observed in the control. On the other hand, the treatments with BA, iP and $m \mathrm{TR}$ had an antagonistic effect on rooting in all three Brachystelma species. In Brachystelma pygmaeum, however, the lower concentrations of BA were found to have the least inhibiting effect on rooting (Figure 5B). No roots were induced in CK-regenerated Brachystelma pulchellum and the control. Nevertheless, the poorly rooted or rootless shoots were transferred to ex vitro conditions. The shoots of Brachystelma ngomense, Brachystelma pulchellum and Brachystelma pygmaeum, however, did not form "spontaneous" roots under ex vitro conditions. A survival rate of $0 \%$ was observed after 2 weeks in the mist house and 1 week in the greenhouse.
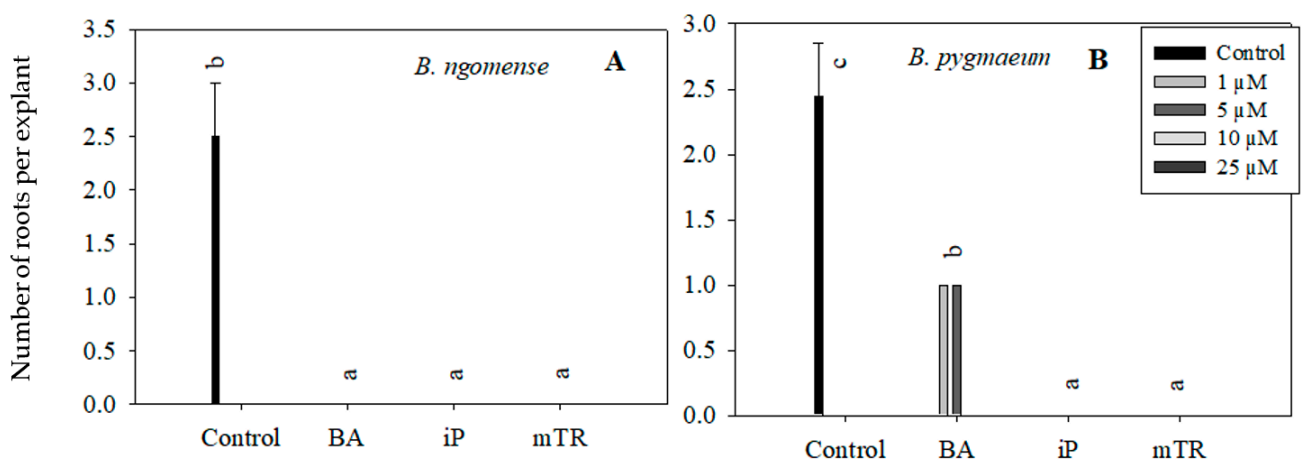

Figure 5. Effect of varying concentrations of cytokinins on the number of roots in (A) Brachystelma ngomense and (B) Brachystelma pygmaeum after six weeks in culture. In each graph, different letter(s) on the bars show significant differences according to Duncan's multiple range test (DMRT) $(p \leq 0.05)$. $N^{6}$-benzyladenine (BA), isopentenyladenine (iP) and meta-topolin riboside ( $m$ TR).
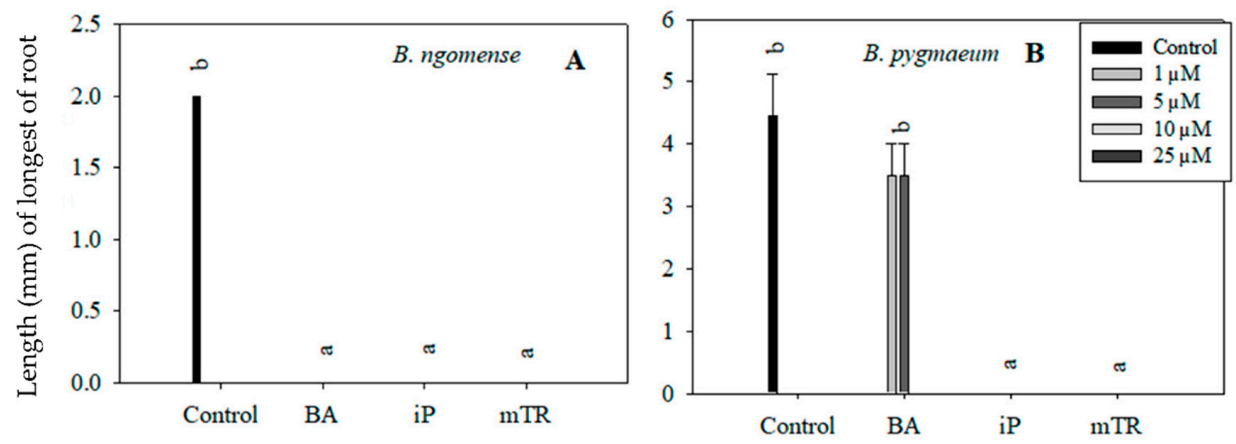

Figure 6. Effect of varying concentrations of cytokinins on the root length ( $\mathrm{mm}$ ) in (A) Brachystelma ngomense and (B) Brachystelma pygmaeum after six weeks in culture. In each graph, different letter(s) on the bars show significant differences according to Duncan's multiple range test (DMRT) $(p \leq 0.05) . N^{6}$-benzyladenine (BA), isopentenyladenine (iP) and meta-topolin riboside ( $m$ TR).

In vitro abnormalities observed in this study include hyperhydricity (Figure A2) and "dwarfing" (Figure A3) in the form of an abundance of small leaves on a short node section. Hyperhydricity mainly affected adventitious shoots derived from the callus. Shoots derived from nodal explants were seldom affected by hyperhydricity. No further morphological differences were observed between the parent plants and regenerants.

\subsection{Effect of Pulsing (Dipping) Treatment on Ex Vitro Rooting and Acclimatization.}

Pulse (dipping) treatment of regenerated shoots with IBA $(100 \mathrm{mg} / \mathrm{L}=492.1 \mu \mathrm{M})$ for $3 \mathrm{~min}$ showed an improved greenhouse survival compared with shoots previously potted directly after in vitro 
root induction. During acclimatization, the shoots derived from this experiment had an extended survival period beyond 10 weeks as opposed to the 7-week survival of the in vitro root induction treatments. This extension can be attributed to the ex vitro root induction that was observed by the fourth week under greenhouse conditions. The survival rate after 4 weeks was 42,35 and $30 \%$ for Brachystelma ngomense, Brachystelma pulchellum and Brachystelma pygmaeum, respectively. By the end of the $10^{\text {th }}$ week, the survival rate was 5\%, $0 \%$ and 3\% for Brachystelma ngomense, Brachystelma pulchellum and Brachystelma pygmaeum, respectively.

The few surviving plants maintained a healthy green appearance with no obvious morphological abnormalities for both the above- and belowground organs (Figure A3). The healthy green appearance was perceived as an indication of functional photosynthetic capacity. Subsequently, Brachystelma pygmaeum shoots derived in vitro were used to test the effect of pulse treatments with $100 \mathrm{mg} / \mathrm{L}$ of IBA at different time intervals (3,12 and $21 \mathrm{~min}$ ). By the end of 8 weeks, the survival rate was $5 \%$ for 3,12 and $21 \mathrm{~min}$, while there was no survival $(0 \%)$ for the control. Thus, the exposure time had no effect on ex vitro root induction and the overall survival of shoots remained low.

\section{Discussion}

Contaminants in plant tissue culture can cause huge economic losses by either making the explant unfit for sub-culture or resulting in its death $[18,19]$. Even though the $1.75 \% \mathrm{NaOCl}$ treatment for $30 \mathrm{~min}$ was found to be the most effective for surface sterilization, a notable number $( \pm 40 \%)$ of explants were lost. Among the likely reasons contributing to contamination in this particular study were the aphids, which were feeding on the stock plants (Figure A2). Plant feeders or pests, especially aphids, do not only contribute to surface contamination but also internal contamination which is an even bigger challenge when attempting to obtain aseptic plants [18]. Thus, for the purpose of optimizing the decontamination success rate, it is necessary to ensure that stock plants are well protected prior to use so as to avoid huge losses [20].

At the culture initiation stage, stem nodal explants of all three species were observed to have new growth either in the form of shoots or callus; however, a notable number of these explants showed no response. Generally, the lack of response from meristematic tissue may be due to bud dormancy or failure in stem elongation [14]. In the current study, some nodal explants taken from various parts of the stem showed no growth response (i.e., no elongation or shoot production). Thus, it is suggested that the reason for this lack of growth response is not based on a specific position on the stem but is likely due to the physiological state of the plant material. The physiological state of an explant determines its biological response; therefore, some explants are more responsive than others at a given time. For instance, callus was frequently observed in Brachystelma pygmaeum compared with Brachystelma pulchellum and Brachystelma ngomense. Callus cultures of Brachystelma pygmaeum were observed to develop adventitious shoots after a period of 6-8 weeks (Figure A2). On the other hand, tuber explants of Brachystelma pygmaeum did not show any indication of new growth during the four weeks in culture. It is likely that there is an absence of meristematic potential in Brachystelma tuber tissue. There have been reports that totipotency is highly likely to be influenced by the presence of plant growth regulators when it does not occur spontaneously [21-23]. Failure to perform subsequent experiments on Brachystelma pygmaeum tubers and to evaluate tubers of the other two Brachystelma species was due to the unavailability of starting plant material. Secondary explants obtained from initiated cultures were used for bulking up plant material.

An increase in shoot numbers as a response to CK treatments has been observed in various micropropagated plants [24]. This observation is thought to reflect the effect of increasing concentrations of CKs during micropropagation $[25,26]$. Even though the results of the current study have not shown a particularly significant difference among the different CKs (BA, iP and $m$ TR), other studies have pointed out the typical differences that result from treatment with CKs belonging to different groups, mainly the aromatic CKs and isoprenoids [27-29]. Differences are also observed even within the CK groups $[17,30]$. Cytokinins, or plant growth regulators in general, have different mechanisms 
of stimulation, depending on factors such as plant species and plant organs. In vitro proliferation rate and biomass accumulation are typically the primary indicators of a CK treatment's stimulation effects [31]. Aromatic CKs, including BA and $m \mathrm{TR}$, are generally known to have a greater influence on developmental processes, mainly those related to morphogenesis and senescence, hereas isoprenoids, including $\mathrm{iP}$, are suggested to be more involved in growth processes concerning the continuation of the cell cycle [32-34]. $N^{6}$-benzyladenine (BA), a synthetic $\mathrm{CK}$, remains the most widely used exogenously applied aromatic $\mathrm{CK}$ in commercial micropropagation due to its effectiveness and affordability, but BA is also known to have deleterious effects on in vitro cultures [17,24,35]. Isopentenyladenine (iP), a natural isoprenoid CK, is also reported to cause physiological abnormalities and to have weak activity in the in vitro propagation of some plant species, especially in comparison with BA $[28,36]$. Thus, other aromatic CKs such as the meta-topolins, which are hydroxylated 6-benzyladenine derivatives, have been identified as possible alternatives [37].

Meta-topolins, including $m \mathrm{TR}$, have generally been observed to not only result in improved shoot proliferation but also cause minimal physiological abnormality [30,38-43]. For instance, Bairu et al. [44] obtained higher shoot multiplication rates from a number of meta-topolin derivatives at different concentrations compared with BA. On the other hand, some studies have reported lower multiplication rates from meta-topolins compared with BA $[30,45,46]$. Meanwhile, some studies show no significant difference between treatments $[47,48]$. Thus, it is evident that responses to plant growth regulator treatments remain species-specific. Generally, the better performance of the meta-topolins has been attributed to their structural advantage when compared with BA $[24,39,49]$. The advantage of the topolin structure is due to the presence of hydroxyl $(\mathrm{OH})$ groups on the benzyl ring, which, during CK metabolism, increase the chances of the formation of $O$-glycosides instead of the deleterious $\mathrm{N}$-glycosides found in BA-treated plantlets [50]. Furthermore, the O-glycoside metabolites are considered stable only at times when they are not required by the plant but are rapidly converted to active CK bases when required [24]. This allows the continuous availability of physiologically active CK over an extended period of time, thus resulting in enhanced shoot formation in vitro [24]. On the other hand, the chemical and biochemical stability of $\mathrm{N}$-glucoside is the reason for their implication in the deleterious effect of BA in plant tissue culture, which may extend to the acclimatization stage [39].

In vitro rooting is controlled by both endogenous and exogenous auxins in plant tissue [39]. Regardless of the absence of exogenous auxins in the medium, cultured plantlets are generally able to produce roots, particularly in a medium without plant growth regulators. However, a medium supplemented with high concentrations of CKs has inhibitory effects. A study by Valero-Aracama et al. [35] reported that higher concentrations of BA and $m$ TR inhibited rooting in Uniola paniculata (sea oats). Similar observations have been made in the current study, where treatment with higher concentrations of BA inhibited in vitro rooting (Figure 5B). On the other hand, $\mathrm{iP}$ and $m \mathrm{TR}$, irrespective of the concentration, inhibited in vitro rooting. Treatment with BA is typically known to reduce acclimatization competence [35,51]; however, in the current study, acclimatization competence was lacking, regardless of the CK treatment.

The decrease in survival in this current study is primarily attributed to the poor rooting, which is commonly observed in micropropagation systems $[52,53]$. Some studies have shown that increasing exposure time promotes rooting [54]. In a study by Phulwaria et al. [55], pulse treatment with IBA $(100 \mathrm{mg} / \mathrm{L})$ for $3 \mathrm{~min}$ was particularly effective in ex vitro root induction for Ceropegia bulbosa. Thereafter, $100 \%$ rooting was observed, which was followed by successful hardening and transfer to the field [55]. Even though the pulse treatment used in this study did not yield a positive result, ex vitro rooting is known to be more advantageous in comparison with in vitro rooting, especially for plants that are difficult to root $[53,55]$.

Concerning acclimatization incompetence, there are a couple of factors that have been reported as possible contributors. Light stress is one of the possible contributing reasons for this short-lived survival, as transfer of plantlets to in vivo conditions of higher light intensity is known to have an overwhelming effect $[53,56]$. Humidity is another factor that changes drastically, thus affecting 
plantlet survival [56]. Successful establishment of plantlets ex vitro, as a concluding step, is crucial in micropropagation because many biotechnological applications are dependent on plant regeneration efficiency [19,57]. Poor survival during acclimatization is often attributed to the heterotrophic mode of nutrition under which the plantlets develop morpho-physiological disorders such as poor control of water loss $[52,53,57]$. However, Brachystelma has been observed to be a naturally fragile group of plants, which might very well be a factor contributing to their poor performance in root development and acclimatization. Perhaps a study involving seed germination may yield better results and also shed some light on the rooting process of Brachystelma species.

\section{Conclusions}

The study demonstrated that Brachystelma species can be manipulated under in vitro culture conditions, though not optimally at present. The manipulation of the culture media with various parameters (in this case, different CK types) and the use of controlled environmental conditions had moderate effects on the development of micropropagation protocols for the three Brachystelma species. Further acclimatization of Brachystelma ngomense, Brachystelma pulchellum and Brachystelma pygmaeum was extremely limited due to the poor rooting that led to short-lived survival under greenhouse conditions. Concerns about a decline in the wild of Brachystelma populations call for an improvement of the available standard micropropagation protocol which can be specifically used in their conservation. Once established, these protocols can also be used with other biotechnological applications involving Brachystelma. The results obtained in the current study provide a stepping-stone for subsequent research towards enhanced rapid clonal propagation of Brachystelma species, which is needed, especially in the absence of efficient alternative conventional propagation techniques.

Author Contributions: Conceptualization, N.P.H. and A.O.A.; formal analysis, N.P.H. and A.O.A.; investigation, N.P.H.; resources, K.D. and J.F.F.; writing—original draft preparation, N.P.H.; writing—review and editing, A.O.A., K.D. and J.V.S.; supervision, J.V.S. and J.F.F.; project administration, J.V.S. and J.F.F.; funding acquisition, J.V.S. and J.F.F. All authors have read and agreed to the published version of the manuscript.

Funding: Financial support provided by the University of KwaZulu-Natal and the North-West University is appreciated. K.D. acknowledges the ERDF project entitled "Development of Pre-Applied Research in Nanotechnology and Biotechnology" (No. CZ.02.1.01/0.0/0.0/17_048/0007323). The article processing charge (APC) was funded by the Faculty of Natural and Agricultural Sciences, North-West University, Mmabatho, South Africa.

Acknowledgments: We are grateful to Adam Shuttleworth for providing the stock material used in this study, A. Young and her staff at UKZN Botanical Garden (South Africa) during the greenhouse stage of the study are greatly appreciated. The administrative support provided by Lee Warren is sincerely appreciated.

Conflicts of Interest: We declare no conflict of interest with regards to the current work. National Research Foundation (NRF) had no role in the design of the study; in the collection, analyses or interpretation of data; in the writing of the manuscript or in the decision to publish the results.

\section{Appendix A}

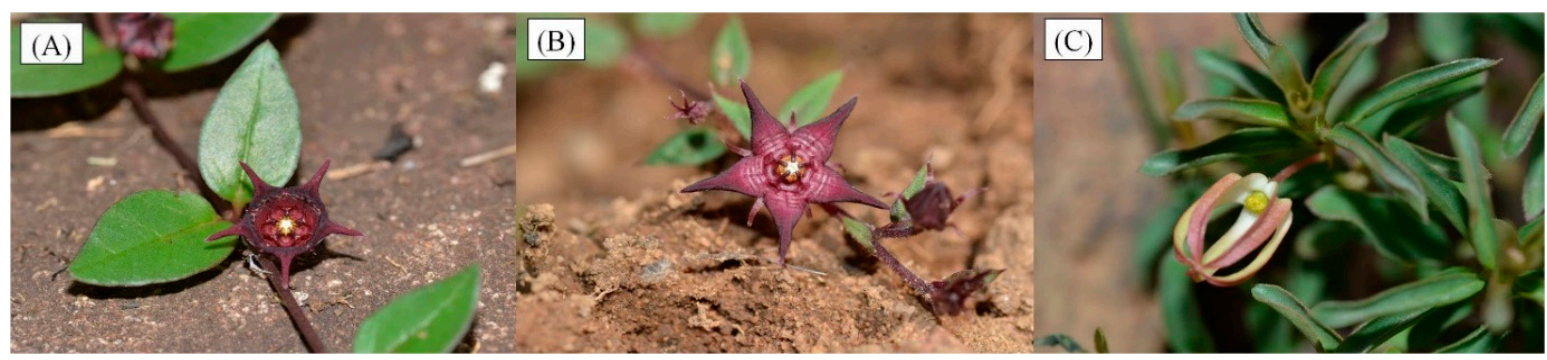

Figure A1. Brachystelma species investigated. (A) Brachystelma ngomense. (B) Brachystelma pulchellum. (C) Brachystelma pygmaeum. (credit: Adam Shuttleworth). 


\section{Appendix B}

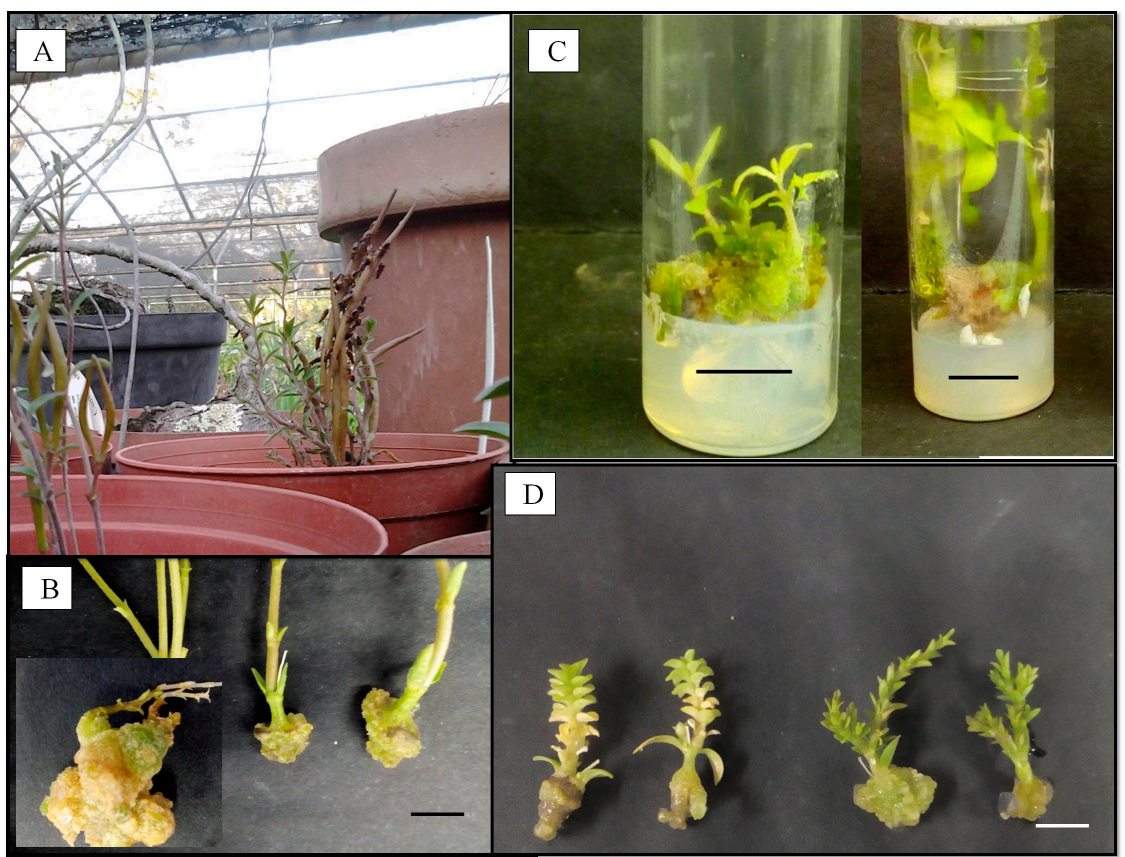

Figure A2. Observations during explant decontamination and bulking up of plant material. (A) Aphids feeding on Brachystelma pygmaeum fruit, contributing to contamination. (B) Callus formed from nodal explants (callus also gave rise to adventitious shoots). (C) Hyperhydric shoots derived from Brachystelma pygmaeum callus cultures on Murashige and Skoog (MS) medium without plant growth regulators. (D) Morphological abnormality of Brachystelma grown in vitro. Scale bar $=10 \mathrm{~mm}$.

\section{Appendix C}

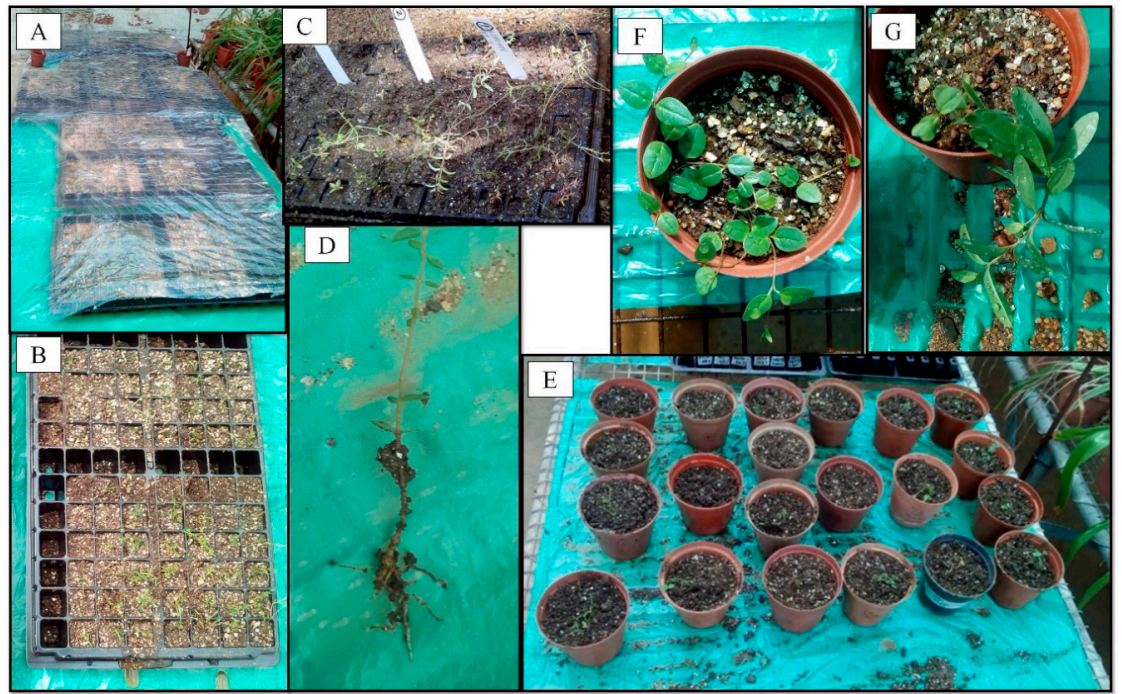

Figure A3. Ex vitro rooting and acclimatization of all three Brachystelma species. (A) Humidity cover retaining moisture during the first week of acclimatization in the greenhouse. (B) Brachystelma species in potting trays in the mist house prior to acclimatization in the greenhouse. (C) Brachystelma species growing in the greenhouse. (D) Ex vitro derived roots on a healthy growing regenerated plant. (E) Brachystelma species, transferred from trays to pots, growing in the greenhouse. (F) Fully acclimatized Brachystelma ngomense. (G) Fully acclimatized Brachystelma pygmaeum. 


\section{References}

1. Bruyns, P.V. A new species of Brachystelma (Apocynaceae) from South Tropical Africa. Novon 2006, 16, 452-453. [CrossRef]

2. Masinde, P.S. A revision of Brachystelma Sims (Apocynaceae: Asclepiadoideaeae-Ceropegia) in East Africa. Kew Bull. 2007, 62, 37-84.

3. South African National Biodiversity Institute (SANBI). Available online: http://redlist.sanbi.org/genus.php? genus=2640 (accessed on 8 February 2015).

4. Bruyns, P.V. Ceropegia, Brachystelma and Tenaris in South West Africa. Dinteria 1984, 17, 3-80.

5. Pooley, E. A Field Guide to Wild Flowers of KwaZulu-Natal and the Eastern Region, 2nd ed.; Natal Flora Publications Trust: Durban, South Africa, 2005.

6. Rajaram, M.S.; Rathod, J.; Dilip, V. Pharmacognostical studies on the tuber of Brachystelma edulis Coll. and Helmsl.- an endemic to Peninsular, India. World J. Pharm. Pharm. Sci. 2014, 3, 1958-1965.

7. Smith, N.M. Ethnobotanical field notes from the Northern territory, Australia. J. Adel. Bot. Gard. 1991, 14, 1-65.

8. Moteetee, A.; Van Wyk, B.E. The medical ethnobotany of Lesotho: A review. Bothalia 2011, 41, 209-228. [CrossRef]

9. Deshmukh, S.; Rathod, V. Nutritional evaluation of some wild edible tuberous plants. Asian J. Pharm. Clin. Res. 2013, 6, 58-60.

10. Pare, D.; Hilou, O.; Ouedraogo, N.; Guenne, S. Ethnobotanical study of medicinal plants used as anti-obesity remedies in the Nomad and Hunter communities of Burkina Faso. Medicines 2016, 3, 9. [CrossRef]

11. Singh, A.K. Probable agricultural biodiversity heritage sites in India: XI. The upper gangetic plains region. Asian Agri-Hist. 2012, 16, 21-44.

12. Venu, P.; Prasad, K. The existential crisis in Indian Brachystelma (Apocynaceae). Curr. Sci. 2015, 109, 680-682.

13. Muthukrishnan, S.; Franklin Benjamin, J.H.; Sathishkannan, G.; Senthil Kumar, T.; Rao, M.V. In vitro propagation of genus Ceropegia and retrosynthesis of Cerpegin-A review. Int. J. Pharm. Sci. Rev. Res. 2013, 22, 315-330.

14. Suttle, G.R.L. Commercial Laboratory Production. In Plant Development and Biotechnology; Trigiano, R.N., Gray, D.J., Eds.; CRC Press: Boca Raton, FL, USA, 2005; pp. 311-319.

15. Krishna, H.; Singh, S.K. Biotechnological advances in mango (Mangifera indica L.) and their future implication in crop improvement-A review. Biotechnol. Adv. 2007, 25, 223-243. [CrossRef] [PubMed]

16. Murashige, T.; Skoog, F. A revised medium for rapid growth and bio assays with tobacco tissue cultures. Physiol. Plant. 1962, 15, 473-497. [CrossRef]

17. Doležal, K.; Popa, I.; Krystof, V.; Spíchal, L.; Fojtíková, M.; Holub, J.; Lenobel, R.; Schmülling, T.; Strnad, M. Preparation and biological activity of 6-benzylaminopurine derivatives in plants and human cancer cells. Bioorganic Med. Chem. 2006, 14, 875-884. [CrossRef] [PubMed]

18. Cassells, A.C. Problems in tissue culture: Culture contamination In Micropropagation, Technology and Applications; Debergh, P.C., Zimmerman, R.H., Eds.; Kluwer Academic Publishers: Dordrecht, The Netherlands, 1991; pp. 31-44.

19. Titov, S.; Bhowmik, S.K.; Mandal, A.; Alam, M.S.; Uddin, S.N. Control of phenolic compound secretion and effect of growth regulators for organ formation from Musa spp. cv. Kanthali floral bud explants. Am. J. Biochem. Biotechnol. 2006, 2, 97-104. [CrossRef]

20. Kane, M.E. Shoot culture procedures. In Plant Development and Biotechnology; Trigiano, R.N., Gray, D.J., Eds.; CRC Press: Boca Raton, FL, USA, 2005; pp. 149-157.

21. Caponetti, J.D.; Gray, D.J.; Trigiano, R.N. History of plant tissue and cell culture. In Plant Development and Biotechnology; Trigiano, R.N., Ed.; CRC Press: Boca Raton, FL, USA, 2005; pp. 9-15.

22. Ascough, G.D.; Novák, O.; Pencík, A.; Rolcík, J.; Strnad, M.; Erwin, J.E.; Van Staden, J. Hormonal and cell division analyses in Watsonia lepida seedlings. J. Plant Physiol. 2009, 166, 1497-1507. [CrossRef] [PubMed]

23. Zaid, A.; Al Kaabi, H. Plant-off types in tissue culture-derived date palm (Phoenix dactylifera L.). Emir. J. Agric. Sci. 2003, 15, 17-35.

24. Amoo, S.O.; Finnie, J.F.; Van Staden, J. The role of meta-topolins in alleviating micropropagation problems. Plant Growth Regul. 2011, 63, 197-206. [CrossRef] 
25. Zhao, Y.; Grout, B.W.W.; Crisp, P. Variations in morphology and disease susceptibility of micropropagated rhubarb (Rheum rhaponticum) PC49, compared to conventional plants. Plant Cell Tissue Organ Cult. 2005, 82, 357-361. [CrossRef]

26. D'Arth, S.M.; Simpson, S.I.; Seelye, J.F.; Jameson, P.E. Bushiness and cytokinin sensitivity in micropropagated Zantedeschia. Plant Cell Tissue Organ Cult. 2002, 70, 113-118. [CrossRef]

27. Ivanova, M.; Van Staden, J. Effect of ammonium ions and cytokinins on hyperhydricity and multiplication rate of in vitro regenerated shoots of Aloe polyphylla. Plant Cell Tissue Organ Cult. 2008, 92, 227-231. [CrossRef]

28. Arinaitwe, G.; Rubaihayo, P.R.; Magambo, M.J.S. Proliferation rate effects of cytokinins on banana (Musa spp.) cultivars. Sci. Hortic. 2000, 86, 13-21. [CrossRef]

29. Dobránszki, J.; Hudak, I.; Magyar-Tábori, K.; Jámbor-Benczúr, E.; Galli, Z.; Kiss, E. How can different cytokinins influence the process of shoot regeneration from apple leaves in 'Royal Gala' and 'M.26'. Acta Hortic. 2006, 725, 191-196.

30. Bogaert, I.; Van Cauter, S.; Werbrouck, S.P.O.; Doležal, K. New aromatic cytokinins can make the difference. Acta Hortic. 2006, 725, 265-270. [CrossRef]

31. Aremu, A.O.; Bairu, M.W.; Novák, O.; Plačková, L.; Zatloukal, M.; Doležal, K.; Finnie, J.F.; Strnad, M.; Van Staden, J. Physiological responses and endogenous cytokinin profiles of tissue-cultured 'Williams' bananas in relation to roscovitine and an inhibitor of cytokinin oxidase/dehydrogenase (INCYDE) treatments. Planta 2012, 236, 1775-1790. [CrossRef]

32. Baroja-Fernández, E.; Aguirreolea, J.; Martínková, H.; Hanus, J.; Strnad, M. Aromatic cytokinins in micropropagated potato plants. Plant Physiol. Biochem. 2002, 40, 217-224. [CrossRef]

33. Ivanova, M.; Novák, O.; Strnad, M.; Van Staden, J. Endogenous cytokinins in shoots of Aloe polyphylla cultured in vitro in relation to hyperhydricity, exogenous cytokinins and gelling agents. Plant Growth Regul. 2006, 50, 219-230. [CrossRef]

34. Holub, J.; Hanuš, J.; Hanke, D.E.; Strnad, M. Biological activity of cytokinins derived from ortho- and meta-hydroxybenzyladenine. Plant Growth Regul. 1998, 26, 109-115. [CrossRef]

35. Valero-Aracama, C.; Kane, M.; Wilson, S.; Philman, N. Substitution of benzyladenine with meta-topolin during shoot multiplication increases acclimatization of difficult- and easy-to-acclimatize sea oats (Uniola paniculata L.) genotypes. Plant Growth Regul. 2010, 60, 43-49. [CrossRef]

36. Strosse, H.; Andre, E.; Sági, L.; Swennen, R.; Panis, B. Adventitious shoot formation is not inherent to micropropagation of banana as it is in maize. Plant Cell Tissue Organ Cult. 2008, 95, 321-332. [CrossRef]

37. Gentile, A.; Jàquez Gutiérrez, M.; Martinez, J.; Frattarelli, A.; Nota, P.; Caboni, E. Effect of meta-topolin on micropropagation and adventitious shoot regeneration in Prunus rootstocks. Plant Cell Tissue Organ Cult. 2014, 118, 373-381. [CrossRef]

38. Werbrouck, S.P.O.; Strnad, M.; Van Onckelen, H.A.; Debergh, P.C. Meta-topolin, an alternative to benzyladenine in tissue culture? Plant Physiol. 1996, 98, 291-297. [CrossRef]

39. Aremu, A.O.; Bairu, M.W.; Szüčová, L.; Doležal, K.; Finnie, J.F.; Van Staden, J. Shoot and root proliferation in 'Williams' banana: Are the topolins better cytokinins? Plant Cell Tissue Organ Cult. 2012, 111, 209-218. [CrossRef]

40. Wojtania, A.; Gabryszewska, E. Effect of cytokinins and amino acids on multiplication of Pelargonium cultivars. Acta Soc. Bot. Pol. 2001, 70, 203-207. [CrossRef]

41. Vinayak, V.; Dhawan, A.K.; Gupta, V.K. Efficacy of non-purine and purine cytokinins on shoot regeneration in vitro in sugarcane. Indian J. Biotechnol. 2009, 8, 227-231.

42. Vasudevan, R.; Van Staden, J. Cytokinin and explant types influence in vitro plant regeneration of Leopard Orchid (Ansellia africana Lindl.). Plant Cell Tissue Organ Cult. 2011, 107, 123-129. [CrossRef]

43. Bairu, M.W.; Stirk, W.A.; Doležal, K.; Van Staden, J. Optimizing the micropropagation protocol for the endangered Aloe polyphylla: Can meta-topolin and its derivatives serve as replacement for benzyladenine and zeatin? Plant Cell Tissue Organ Cult. 2007, 90, 15-23. [CrossRef]

44. Bairu, M.W.; Stirk, W.A.; Doležal, K.; Van Staden, J. The role of topolins in micropropagation and somaclonal variation of banana cultivars 'Williams' and 'Grand Naine' (Musa spp. AAA). Plant Cell Tissue Organ Cult. 2008, 95, 373-379. [CrossRef]

45. Rosales, M.S.D.; Solís, Á.G.A.; Méndezy, N.L.V.; Balch, E.P.M. Effect of cytokinins on the in vitro propagation of Mexican Agaves. Rev. Fitotec. Mex. 2008, 31, 317-322. 
46. Niedz, R.P.; Evens, T.J. The effefects of benzyladenine and meta-topolin on in vitro shoot regeneration of Citrus citrandarin rootstock. Res. J. Agric. Biol. Sci. 2010, 6, 45-53.

47. Salvi, N.D.; George, L.; Eapen, S. Micropropagation and field evaluation of micropropagated plants of turmeric. Plant Cell Tissue Organ Cult. 2002, 68, 143-151. [CrossRef]

48. De Diego, N.; Montalbán, I.A.; Moncaleán, P. In vitro regeneration of Pinus spp. adult trees: New method for obtaining clonal plants. Acta Hortic. 2010, 865, 361-366. [CrossRef]

49. Moyo, M.; Finnie, J.F.; Van Staden, J. Topolins in Pelargonium sidoides micropropagation: Do the new brooms really sweep cleaner? Plant Cell Tissue Organ Cult. 2012, 110, 319-327. [CrossRef]

50. Bairu, M.W.; Novák, O.; Doležal, K.; Van Staden, J. Changes in endogenous cytokinin profiles in micropropagated Harpagophytum procumbens in relation to shoot-tip necrosis and cytokinin treatments. Plant Growth Regul. 2011, 63, 105-114. [CrossRef]

51. Werbrouck, S.P.O.; Van der Jeugt, B.; Dewitte, W.; Prinsen, E.; Van Onckelen, H.A.; Debergh, P.C. The metabolism of benzyladenine in Spathiphyllum floribundum schott 'petite' in relation to acclimatization problems. Plant Cell Rep. 1995, 14, 662-665. [CrossRef]

52. Xiao, Y.; Niu, G.; Kozai, T. Development and application of photoautotrophic micropropagation plant system. Plant Cell Tissue Organ Cult. 2011, 105, 149-158. [CrossRef]

53. Debergh, P.C.; Read, P.E. Micropropagation. In Micropropagation, Technology and Applications; Debergh, P.C., Zimmerman, R.H., Eds.; Kluwer Academic Publishers: Dordrecht, The Netherlands, 1991; pp. 1-13.

54. Madhulatha, P.; Anbalagan, M.; Jayachandran, S.; Sakthivel, N. Influence of liquid pulse treatment with growth regulators on in vitro propagation of banana (Musa spp. AAA). Plant Cell Tissue Organ Cult. 2004, 76, 189-192. [CrossRef]

55. Phulwaria, M.; Shekhawat, N.S.; Rathore, J.S.; Singh, R.P. An efficient in vitro regeneration and ex vitro rooting of Ceropegia bulbosa Roxb.-A threatened and pharmaceutical important plant of Indian Thar Desert. Ind. Crop. Prod. 2013, 42, 25-29. [CrossRef]

56. Chandra, S.; Bandopadhyay, R.; Kumar, V.; Chandra, R. Acclimatization of tissue cultured plantlets: From laboratory to land. Biotechnol. Lett. 2010, 32, 1199-1205. [CrossRef]

57. Yang, S.H.; Yeh, D.M. In vitro leaf anatomy, ex vitro photosynthetic behaviors and growth of Calathea orbifolia (Linden) Kennedy plants obtained from semi-solid medium and temporary immersion systems. Plant Cell Tissue Organ Cult. 2008, 93, 201-207. [CrossRef]

Publisher's Note: MDPI stays neutral with regard to jurisdictional claims in published maps and institutional affiliations.

(C) 2020 by the authors. Licensee MDPI, Basel, Switzerland. This article is an open access article distributed under the terms and conditions of the Creative Commons Attribution (CC BY) license (http://creativecommons.org/licenses/by/4.0/). 